\title{
The role of digital technologies in strengthening Russia's position in the global oil market
}

\author{
Kuzmina Violetta Mihailovna \\ of the Department of International \\ Relations and Public Administration of \\ SWSU \\ South West state University \\ Kursk, 50 let Oktyabrya ul. 94 \\ 380040, Russia \\ kuzmina-violetta@yandex.ru \\ ttps://orcid.org/0000-0002-1867-7330
}

\begin{abstract}
The relevance of this study lies in the fact that the modern oil market is characterized by instability and high competition. Depletion of oil fields, depreciation of equipment for oil production, price instability and political conflicts have a negative impact on Russia's position on the global energy market.
\end{abstract}

The aim of the work is to study the place and role of the Russian Federation on the world oil market.

As research methods include:The source materials for the analytical study were statistical data from official sources: the Center for Macroeconomic Analysis and Short-term Forecasting, the Ministry of Economic Development of Russia, Ru-Stat, the Analytical Center for the Government of the Russian Federation.Significant statistical and analytical support was provided by strategic reports on Gazprom Neft and the LUKOIL oil company.

Russia does not want to stop there.The Strategy states that the support and development of the energy sector of the Russian Federation should be carried out in stages. The concept of an intellectual field (LIFE-Field), implemented in the company "LUKOIL", is to integrate the field management processes based on automated computer systems and high-tech data collection systems.

A key component of the digital production concept is the use of certain software that allows all employees of the oil sector to carry out their activities more quickly and efficiently.

Keywords-information technology, world oil market, Russia, Gazpromneft, Rosneft, digital technologies

\section{INTRODUCTION}

Oil is one of the most important commodities in the global market. The states actively use this natural resource, increasing the volumes of extraction and production. One of the factors for the development of the state's economy is the successful processing of oil and the production of petroleum products from it, the use of oil in various industries, and not only as an export of raw materials. Russia is the only one among the major industrialized countries of the world, which is not only fully provided with oil, but also exports fuel to a considerable extent. Its share in the global balance of fuel and energy resources is large. The relevance of this study lies in the fact that the modern oil market is characterized by instability and high competition. Depletion of oil fields, depreciation of equipment for oil production, price instability and political conflicts have a detrimental effect on Russia's position in the global energy market.

The aim of the work is to study the place and role of the Russian Federation in the global oil market.

To achieve this goal it is necessary to solve the following tasks:

- to consider the main trends in the development of the world oil market;

- to study the development of the system of legal regulation of the world oil market;

- to reveal the importance of innovative technologies in changing the place and role of Russia in the oil market.

The subject of research is the oil market as a special segment of the global economy.

The object of the research is the state of the modern Russian oil market in the context of the economic transformation of the world picture.

Recent studies of domestic and foreign authors differ greatly in the role and assessment of Russia in the global oil market. They are distinguished primarily by the level of operating with statistical data, access to the completeness of information and the level of politicization of the research. Syed Abul Basher, Alfred A. Haug, Perry Sadorsky provide objective information about Russia's place on the world oil market compared to the yield of crude oil reserves in Canada, Norway, Russia, Kuwait, Saudi Arabia and the United Arab Emirates[1]. The authors argue that oil reserves affect stock returns in Canada, Russia, Kuwait and the United Arab Emirates. Oil supply shocks are important for the UK, Kuwait and the United Arab Emirates. Mexico is the only country where stock returns are not affected by shocks in the oil market.

Elena Tuzova, Faryal Qayum, in her study showed the interconnection of Russia's positions on the world oil market in the context of the sanctions against Russia[2]. The results showed a significant impact of oil prices on the Russian economy. Researchers predict that Russia's economic prospects are not very optimistic and real GDP for the quarter by quarter will decline by an average of 19 percent over the next two years. 
Adnan Vatansever touches another vector of Russia's position on the world oil market, associated with the construction of pipelines[3]. The consequences of Russia's excess capacity can be significant for Europe and Asia. As for oil, the maneuvering space is wide enough to allow Russia to abandon the whole route of its choice.

Domestic researchers (A. Goeppert, D. Ola, S. Prakash) reveal the importance of introducing innovative technologies in the extraction and development of oil fields, without which it will be difficult for Russia to find its niche in the modern oil market[4].

Stupin V.V. notes significant territorial-structural shifts in the oil industry of the world for Russia, and considers it necessary for Russia to take advantage of a favorable situation[5]. A similar opinion is shared by Filimonova I.V.[6]

A. Bondar in his study notes that US sanctions have become a kind of catalyst for strengthening Russia's position on the world oil market[7]. But R. Ivanov. Believes that not everything is so optimistic for our country and offers three scenarios for the development of world energy until 2050, in which Russia is far from leading positions on the world oil market.

Thus, the relevance of the study of this topic is obvious.

\section{MATERIALS AND METHODS}

Articles, publications of domestic economists and political scientists, statistical data, information posted on the websites of the Ministry of Economic Development and the Ministry of Energy of the Russian Federation, reports of the largest oil companies were used in this work.

Analysis and synthesis of scientific literature, analysis of documents, statistical data, as well as an illustrative-graphic method were used as methods of research.

The source materials for the analytical study were statistical data from official sources: the Center for Macroeconomic Analysis and Short-term Forecasting [7], the Ministry of Economic Development of Russia[8], RuStat [9], the Analytical Center for the Government of the Russian Federation [10].

Significant statistical and analytical support was provided by strategic reports on Gazprom Neft [11] and the LUKOIL oil company [12].

We used standard methods of statistical data processing with their subsequent analytical substantiation.

\section{RESULTS}

The oil and oil products market is a very thin and sensitive system, the state of which depends on many factors: political, economic, technological, on the level of oil production, etc. However, this market is fairly well organized, has its own characteristics and rules of the game.

Today, the subjects of the oil market are international oil companies, national oil companies, as well as small local companies. Some of the most influential companies in the global oil market are [13]:
- Exxon Mobile (market capitalization of \$ 363.3 billion, USA);

- PetroChina (market capitalization of \$203.8 billion, China);

- Chevron (market capitalization of \$ 192.3 billion, USA);

- Total (market capitalization 121.9 billion dollars, France);

- Sinopec (market capitalization of $\$ 89.9$ billion, China);

- Royal Dutch Shell (market capitalization of 210 billion dollars, the Netherlands);

- Gazprom (market capitalization of \$ 57.1 billion, Russia);

- Rosneft (market capitalization of \$ 51.1 billion, Russia);

- Reliance Industries (market capitalization of 50, 6 billion dollars, India);

- LUKOIL (market capital isation of \$ 37 billion, Russia).

Oil is produced in various regions of the world. The largest states in terms of deposits of "black gold" are the following: Venezuela, Saudi Arabia, Canada, Iran, Iraq and Kuwait.

To ensure safety in the global oil market, a number of documents and regulatory acts are in place that regulate various aspects of relations in this sector.

One of the well-known energy regulatory instruments is the Energy Charter of 1991. This is a political declaration that expresses the principles of international cooperation in the energy sector on the basis of a common interest in reliable energy supply and sustainable economic development.

Participation in the Energy Charter process is not limited to the signing of the Energy Charter Treaty. The Energy Charter is not only a legal basis, but also a multilateral political forum in which governments of different states take part in a dialogue on cooperation in the energy sector.

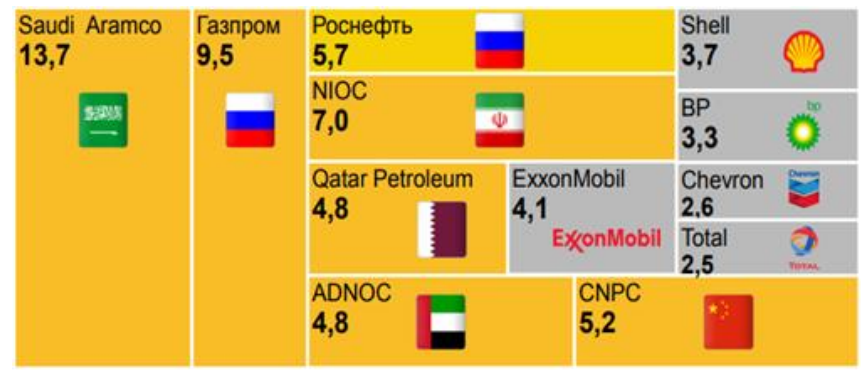

Fig. 1 - Hydrocarbon production by the largest oil and gas companies in the world, mln barrels BC / day

International treaties are the most important sources of energy law. One of the intergovernmental agreements in the energy sector is the Vienna Convention on the International Sale of Goods, since a large amount of energy equipment, 
which is necessary for the construction and operation of energy facilities, is purchased in different countries.

There is a wide range of different documents in the field of oil and gas regulation in the Russian Federation. They are the following: Federal Law 'On Subsoil', 'On energy saving and energy efficiency improvements and on Amendments to Certain Legislative Acts of the Russian Federation', 'On the safety of fuel and energy facilities', 'On the state information system of the fuel and energy complex' , the order of the Government of the Russian Federation 'On the approval of the Energy Russian strategy until 2030'.

Every year, the Russian Federation extracts about 550 million tons of oil and immediately almost half of the extracted oil is refined. Russia confidently ranks second in the world in oil exports, behind the first place in Saudi Arabia. The main buyers of energy from Russia are such countries as the Netherlands, China, Germany, South Korea, Poland, Japan, Italy, Belarus, Turkey, Finland.

In 2018, the fuel and energy complex showed stable dynamics not only in production, but in export. Oil exports in 2018 amounted to 260.2 million tons, an increase of $2.9 \%$ or 7.4 million tons compared with 2017. In 2018, oil exports were mainly directed to China (67 million tons), the Netherlands (42.2), Germany (23.3), Belarus (18.3), Poland (17.6), Korea (15.3), Italy (13.1) and Finland (10.2). Exports of petroleum products in 2018 amounted to 150.1 million tons (an increase of $1.1 \%$ or 1.6 million tons by 2017). This is the fifth result in history, inferior to the period of 2013 2016 (2015 maximum was171.7 million tons), but before that the supplies were significantly less.

TABLE I. COUNTRIES PURCHASING OIL AND OIL PRODUCTS FROM RUSSIA, 2017-2018 [14]

\begin{tabular}{|l|l|c|c|}
\hline № & Country & $\begin{array}{c}\text { Amount, billion dollars } \\
(\mathbf{2 0 1 7 - 2 0 1 8} \text { years })\end{array}$ & $\begin{array}{c}\text { \% } \\
\text { Share }\end{array}$ \\
\hline 1 & China & 55,3 & 15,9 \\
\hline 2 & Netherlands & 55,1 & 15,8 \\
\hline 3 & Germany & 23,7 & 6,8 \\
\hline 4 & South Korea & 19 & 5,5 \\
\hline 5 & Poland & 17,1 & 4,9 \\
\hline 6 & Japan & 15,1 & 4,3 \\
\hline 7 & Italy & 14,1 & 4,1 \\
\hline 8 & Belarus & 13,2 & 3,8 \\
\hline 9 & Turkey & 11,3 & 2,7 \\
\hline 10 & Finland & 9,48 & \\
\hline
\end{tabular}

«Oil and gas companies need to understand how new information technologies can be applied in order to gain competitive advantages», said Richard Holsman, head of digital technologies in the energy industry at Accenture. Giants such as Shell or ExxonMobil are already using digital technology to control the development of projects using mobile devices. For the exploration and production segment, this means that all the information about the development of the field is processed and, with the help of special applications, is displayed on the mobile devices of interested persons in real time.. The project operator can see on his tablet how drilling or production is going, and the top manager can see business analytics. Mobility in this case provides round-the-clock control and quick decisionmaking.

At the present stage of development in Russia digital technologies are actively developing. Given the specialization of the Russian Federation in the primary industries and the dependence of the state on oil production and exports, the introduction of digital technologies in domestic oil companies will make a significant contribution to the development of the country's economy. The main oil producing companies in Russia are: Gazprom Neft, Rosneft, Lukoil, Surgutneftegaz. Consider what digital technologies are used in these companies.

Gazprom Neft is the leader in Russia in the implementation of information technologies and automation of oil refining processes. At the refineries of the company, virtual quality analyzers are actively used - mathematical models that make it possible to predict quality indicators without actually measuring them, on the basis of previously performed laboratory tests [15].

The relevant areas in this area are the creation of models and the performance of experimental studies of processes occurring in the natural environment, the development of software for processing and interpreting geological and geophysical data, and so on. These developments will assist in obtaining virtual images of production facilities that will speed up the process of creating new types of equipment, design and construction.

In the oil industry, the trend has affected all areas - from production to sales. A modern field, and even more so a field of the future, is unthinkable without constant monitoring of the state of wells and downhole equipment, pipelines and surface infrastructure. The obtained data allows you to track production indicators in real time, respond to process changes in a timely manner, prevent breakdowns and accidents, save energy and other resources. Further processing and analysis of information makes it suitable for use in planning and making high-quality managerial and strategic decisions. The result of the introduction of "smart" automation in the fields optimization of drilling. and increased oil recovery, savings in operating costs up to $25 \%$. As for further development, an increase in the number of sensors, an improvement in their technical characteristics, and an increase in operating efficiency are certainly important, but the main task is still in a more intellectual plane. All of these multi-byte datasets must be turned into a full-fledged asset that brings profit to the company. Only in this case, the cost of automation is fully justified. Ideally, a fully automated refinery is a plant where information from any sensors and any processes is accumulated, systematized, analyzed and forms the basis of models that allow you to make strategic decisions at the highest level. That is, thanks to information technology, the value of data must multiply, and they themselves must become a commercial resource.

«Rosneft» is the largest oil and gas company in the Russian Federation and the largest in the world in reserves and production of liquid hydrocarbons among other public oil and gas companies. This company shows a steady 
increase in the volume of economically viable hydrocarbon reserves. In 2017, Rosneft PJSC presented the Rosneft-2022 strategy, in which digitalization was called the most important element of further business development. Thus, in the field of exploration and production, the task of technological breakthrough is posed, which can be solved by optimizing digital models for developing key mining projects using productivity-enhancing technologies, 3D / 4D geomechanical and physico-chemical modeling. To achieve the goals of the Rosneft-2022 strategy, the company has already signed an agreement with General Electric on the creation of a joint venture focused on the introduction of modern digital technologies and new industrial Internet standards. The introduction of the latest digital solutions will optimize the system for collecting, processing and analyzing industrial data.

The second largest company in Russia is 'Gazprom Neft'. Gazprom Neft is introducing digital technologies to improve the efficiency of exploration and production since the foundation of its company. In 2012, it was decided to proceed to the implementation of a large-scale project "Electronic development of assets" (ERA). This project is designed to ensure the operational management of key production stages (monitoring of well operation, analysis and control of production, selection of the optimal field development system). ERA was an important step towards the effective use of digital technologies in mining, which allowed the company to achieve improved process efficiency. The next stage was the development of a comprehensive concept of "digital" production. Thus, the concept of "digital field" appeared - the field in the future, the most effective and safe. Work on this concept began in 2013 and Gazpromneft-Khantos was chosen as the platform for applying this new technology, since this division of the company is one of the most modern and advanced from a technological point of view [15].

At the present stage of development, all Gazprom Neft refineries are equipped with digital distributed control systems (RSU). Also, to improve the efficiency of work, Advanced Management Systems (APC) have been developed and implemented. The introduction of such systems is one of the current areas of development at the company's refineries, as they represent a kind of autopilot, which takes on the function of making decisions in case of departure from the regulatory regime

New technologies and communication capabilities, among other things, change the appearance of the average production employee, it does not matter whether it is a drilling or oil refinery. Linking industrial and information technologies together leads to the fact that human participation in production processes is reduced to remote observation and timely adjustment of parameters. In turn, the development of mobile applications allows us to talk about future changes in the very principle of decisionmaking: the main role will be played by the opinion of not one specialized specialist, but the multi-competent expert community.

Such system solutions are already being introduced by world giants of the oil industry. Russian companies do not yet have full-fledged platforms for joint cooperation, but the tendency for their emergence is already visible. For example, Gazprom Neft has created a Competence Center, which brings together geologists, developers, seismic scientists from the Scientific and Technical Center, the corporate center and its subsidiaries. Due to his work, today it is possible to find solutions for difficult cases in the process of drilling new wells and developing new reserves [15].

The employees of the center work on the GeoMate information system platform, developed with the participation of experts from Gazpromneft NTC and IT specialists of the company. However, today Gazprom Neft is only at the beginning of the journey to master all the possibilities of modern information technologies.

In 2017, 'Gazprom Neft' strengthened its leading position in the Russian oil industry. Confidently increased production and financial performance, net profit. This success is mostly determined by the development of deposits in the Arctic zone. At the company's refineries, construction of new production facilities continued as part of the second stage of a large-scale asset modernization program.

This is how the "Digital Field" appeared - the image of the field of the future, as efficient and safe as possible. Work on the concept began in the fall of 2013 with a meeting with major vendors. It was decided to use the most successful international experience, taking into account the specifics of Gazprom Neft assets. Gazpromneft-Khantos, one of the most modern and technologically advanced mining companies of the company, was chosen as a platform for running in.

In general, the concept of "Digital Field" in the company combines several basic "digital" approaches: the use of updated geological and engineering models, operational production management, integration with financial and economic indicators, the accumulation of knowledge and experience and the creation of a single database and, of course, teamwork and joint decision making[15].

The implementation of such projects is a multi-stage and painstaking task. It is necessary to assess the existing situation, highlight the processes where the "digital" approaches will give the greatest effect, prioritize and understand the necessary conversion depth for each of them, and finally create a roadmap. Some of the technologies that in the future will undoubtedly enter the Digital Field have already been introduced or are being developed at Gazprom Neft. For example, the key to successful development of complex geological objects is the constant updating and refinement of the reservoir model. This work is already underway in the company: an in-house development, the GeoMate system, is being introduced to accumulate and analyze geological and field data. Within each Digital Field program, the task of integrating data from different sources is solved. Technically, for this purpose different approaches and tools are used. As part of the overall IT strategy, Gazprom Neft provides for the creation of a special platform for collecting, merging and storing data from different disciplines about the same fields and wells (in terms of geology, drilling, and economics). 


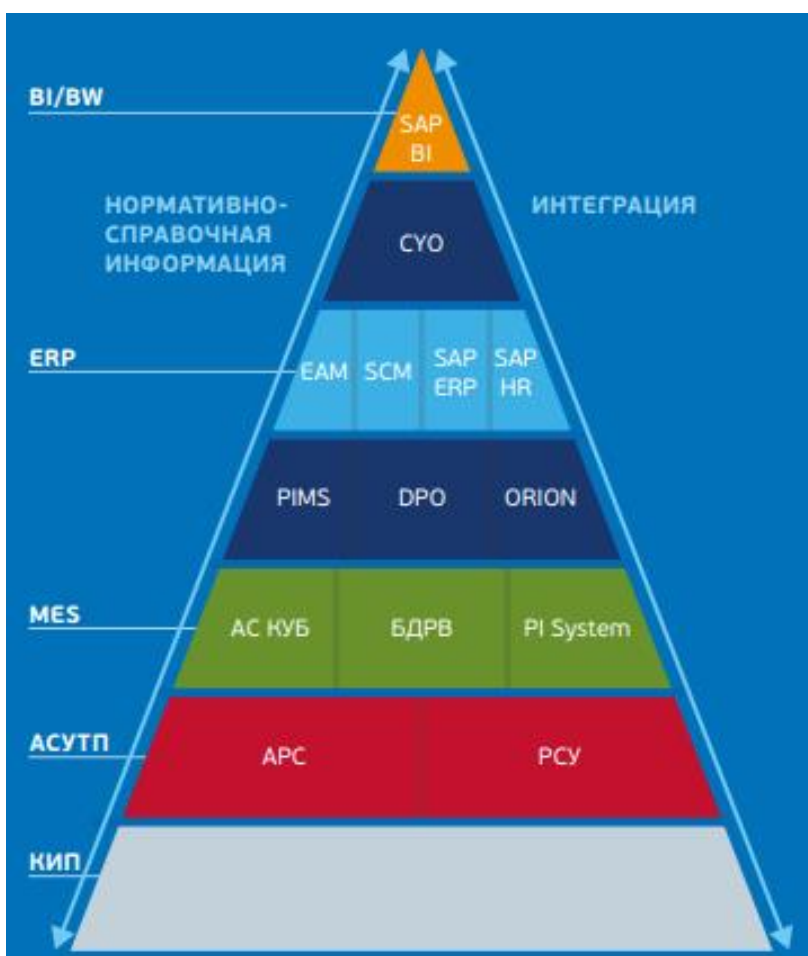

Fig. 2 - The pyramid of information technology in the oil companies of Russia[16]:

- $\mathrm{BI} / \mathrm{BW}$ - an information system designed to solve business analysis problems, allows you to process large amounts of data and build implicit dependencies, generate reports when accessing various data sources;

- $\quad$ TOPO - maintenance and repair of equipment;

- ERP -organizational and information system, integrating production and operations, human resource management, financial management and asset management, focused on the optimal use of enterprise resources;

- $\quad$ EAM - Enterprise Asset Management:

- an information system aimed at the optimal management of physical assets and their modes of operation, risks and expenses throughout the entire life cycle for achieving and implementing the organization's strategic plans;

- $\quad$ SCM - information system designed to automate and control all stages of the company's supply and to control the entire product distribution. Covers the entire product cycle: the purchase of raw materials, production, distribution of finished products;

- MES - information system designed to solve problems of synchronization, coordination, analysis and optimization of production within the enterprise;

- АСУТП - automated process control system: a group of hardware and software designed to automate the process equipment control at industrial enterprises;

- $\quad$ APC - Advance Process Control:advanced process control;

- $\quad$ PCY - (DCS -Distributed Control System) - process control system, characterized by the construction of a distributed inputoutput system and decentralization of data processing. As a rule, they are used to control continuous technological processes.

Today, there are a number of factors that impede the effective development of Russia in the energy sector.

The first factor is the tax on customary minerals, the tax on the reproduction of the mineral resource base and a number of other taxes.
The second factor is the constantly changing price of oil itself. But here we can give a different assessment of the impact of oil prices on the economic situation in Russia. Initially it is important to understand that oil is the most complex type of raw material for analysis than other resources. On this basis, an increase in oil prices can have both positive and negative effects on development in the short and long term.

On the one hand, the rise in price of oil increases the value of exports, which has a positive effect on the balance of payments. However, at the same time, this process automatically leads to an increase in gasoline prices. As a result, the purchasing power of consumers decreases, this negatively affects the sales of companies, and they begin to pay less taxes to the state's treasury.

The third factor restraining development is the dependence of Russian exports on foreign markets, especially European and Asian. The strengthening of environmental restrictions on exports, as well as the policy pursued by the European Union to diversify energy supply sources, already leads to a reduction in oil exports.

Another important issue is the utilization of petroleum gas. In large oil fields, which are located quite far from industrial centers, petroleum gas is often burned. It is necessary to create installations or small plants for its utilization using the developments of scientists.

The fifth factor is a high degree of wear and tear of equipment for oil production. Corrosion is one of the significant factors that causes damage to oil-producing equipment and reduces the residual resource of its operation. In most cases, corrosion during the extraction and transportation of oil occurs due to the presence of three main substances - hydrogen sulfide, carbon dioxide and water.

Russia occupies a high niche in the world in the extraction and processing of oil. The state pays great attention to the energy industry. To support the oil industry, the government approved the Energy Strategy of Russia for the period up to 2035. This program has developed a specific target scenario, according to which until 2035 it is planned to use all the advantages of the oil and other energy sectors of Russia as efficiently as possible. This can be achieved through the following measures [16]:

- increase in value added for petroleum products;

- the progressive development of the oil industry in the Far East and Siberia;

- increasing the innovation component for oil production and refining to reduce costs;

-stimulation of the development of additional investments in the oil industry of the Russian Federation due to the large influence of the industry on the country's economy.

Increasing production and improving its efficiency is impossible without intensifying the use of scientific and technological progress in the industry, improving drilling methods, influencing the reservoir, increasing the extraction of reserves and introducing other advanced oil production technologies that will make economically justified the use of hard-to-recover oil reserves. 
In order to approach the production of petroleum products to their consumers, it is necessary to build new highly efficient refineries in areas of concentrated consumption of petroleum products, and in the remote northern and eastern areas to develop certified small plants with a full oil refining cycle.

\section{IV. .DISCUSSION}

Considering the energy strategies of importing countries of Russian oil and general forecasts for the global energy market in the long term, we can trace one common feature this is a significant reduction in the use of non-renewable energy sources, the transition to "environmental" energy.

For example, China is striving for efficient, selfsufficient, environmentally friendly and innovative energy production and consumption. At present, China relies on foreign exports for almost $60 \%$ of its oil, with Saudi Arabia, Angola and Russia being the largest suppliers of oil. In 2018, a paper was presented on the development of China's energy sector until 2050. The published document shows that by 2050 , China can build a low-carbon economy with extremely low emissions, based on renewable energy sources.

In the Energy Concept of Germany until 2050, it all comes down to the fact that the state is making a transition to the era of renewable energy sources. Nowadays more than half of the total volume in the structure of all areas of Germany's energy sector is oil products $(34.6 \%)$ and gas $(21.7 \%)$. As far as oil is concerned, out of its own proven reserves, Germany can cover only $4 \%$ of the volume necessary for the normal functioning of the country's economy [15] .

Nowadays the task of making Germany the first country in the world, which will completely have switched to energy derived from environmentally friendly sources by 2050 is on the agenda of the German government in the energy sector. From a technical and economic point of view, according to experts of the Federal Agency for Environmental Protection, this plan will be implemented even on the basis of existing technologies.

As for the energy sector, it is possible to achieve highimpact, energy-efficient, resource-saving and geo-ecological production with the help of innovative technologies. They contribute to the search for new oil and gas fields, an increase in the coefficient of extraction of reserves and the depth of processing of raw materials, reducing losses during production and transportation.

There are five groups of innovation development:

-oil and gas innovations in the field of prospecting and exploration of deposits;

Innovative technologies of production and increase of oil and gas;

- innovative technologies in the field of oil refining;

- oil and gas infrastructure of a new generation;

- use of IT-innovations in the production processes of oil and gas companies.

To date, there are almost no undeveloped easily accessible deposits. Geologists are trying to find ways of oil production in harsh natural conditions, remote areas with a complex structure of rocks. The main method used in the study of the subsoil is seismic. When used, an artificial source excites elastic waves. The seismic receivers record information, and then the data is processed and interpreted. Oil and gas innovations such as electrical exploration and high-density seismic UniQ helped to increase the number of sources and receivers of waves and increase the accuracy of research. Another innovation in the field of search is the beam modeling technique, which calculates the optimal layout of the excitation sources and recording equipment. With the help of 4D seismic, oil and gas basins having a complex structure are modeled, changes in deposits are assessed, the accuracy of predicting oil and gas potential is increased, the effectiveness of prospecting, detection and technical preparation for further development of the field is increased, and the efficiency of the resource base is increased. The introduction of innovations contributes to the growth of recoverable reserves and reduces investment in production drilling.

The LUKOIL Group has developed the world's first actuators based on valve electric motors, which have a combination of characteristics that allow for the implementation of an optimal technological mode for selecting well production with minimum energy consumption and maximum resource. Valve electric motors reduce energy consumption during oil production due to higher efficiency values and lower operating currents, as well as due to the possibility of controlling rotational speed and cyclical operation. In the future, it is planned to replace the entire stock of wells equipped with asynchronous engines with valve ones [17].

The scientific research institute of the LUKOIL group has developed a technology that does not have any analogues in the world to process waste generated at refineries in the process of producing a high-octane gasoline component. This technology makes it possible to obtain calcium fluoride from these wastes, which can be used in the metallurgical industry as a full-fledged substitute for imports of fluoride spar, a natural analogue of calcium fluoride, in demand on the market.

The concept of an intellectual field (LIFE-Field), implemented in the company "LUKOIL", is to integrate the field management processes based on automated computer systems and high-tech data collection systems. The concept covers the full production cycle of the project, from the search and exploration stage to the completion of development, and includes such units as integrated modeling, integrated planning, an integrated operations center, etc. The main source for such optimizations is identification of bottlenecks followed by effective elimination. For example, a significant effect is provided by an increase in the coordination of geological modeling and modeling of the field infrastructure development.

The most complete intellectual field technology has been implemented on the Company's largest foreign projects in Uzbekistan and Iraq. In Russia, the Company actively applies such technologies in the Caspian Sea and in the Urals, while conducting work on their implementation in other regions of operations.sv 


\section{CONCLUSION}

Today we can single out the main foreign economic interests of Russia for the development of the state's economy:

- creation of an integrated support system for competitive domestic products in foreign markets;

- development of economic, political and trade relations within the framework of the Eurasian Economic Union and the formation of joint competitive advantages in the global division of labor;

-the formation and development of the system of import substitution, active promotion of competitive Russian import-substituting industries, especially export-oriented ones;

- building stable diversified ties with world economic centers that increase the long-term sustainability of the development of the Russian economy;

-strengthening trade and economic relations with China, India, Brazil, Mexico, South Africa, Egypt, Saudi Arabia, South Korea, Turkey, ASEAN countries and other states of the Asia-Pacific region, the Middle East, Africa and Latin America;

- achieving leading positions in the implementation of energy supplies to world markets based on geographic and product diversification of exports, participation in the formation of the global energy infrastructure and the development of rules for the functioning of global energy markets.

- One of the priorities of Russia's foreign economic policy is to increase Russia's role in ensuring global energy security and strengthening its position in the hydrocarbon market.

Changing of geographical structure of the world oil market contributed to a reversal of the main energy consumption towards the Asia-Pacific region.

Oil is the national wealth of the Russian Federation, the source of the country's high status in the global energy market and the foundation of its economy.

The Institute of Energy Strategy (Russia) presented three main scenarios for the development of world energy:

- inertial catastrophic;

-stabilization- stagnation;

- innovative and revolutionary.

Each of these scenarios has its own path and scale of energy demand. All three projections involve two stages: until 2030, and the period from 2030 till 2050. At the first stage, the forecasts roughly converge: the world energy sector will retain the current state with a few exceptions. Since Russia depends on the sale of oil and other energy resources, by 2050 the prospect will not have been the best. We can expect a strong crisis in the economy, since most of the income to the Russian budget comes from the export of oil and gas. Though many countries are in the course of leaving energy dependence by 2050 , it is possible.
To date, there are almost no undeveloped easily accessible deposits. Geologists are trying to find ways of oil production in harsh natural conditions, remote areas with a complex structure of rocks. The main method used in the study of the subsoil is seismic. When used, an artificial source excites elastic waves. Oil and gas innovations such as electrical exploration and high-density seismic UniQ helped to increase the number of sources and receivers of waves and increase the accuracy of research. Another innovation in the field of search is the beam modeling technique, which calculates the optimal layout of the excitation sources and recording equipment. With the help of $4 \mathrm{D}$ seismic, oil and gas basins having a complex structure are modeled, changes in deposits are assessed, the accuracy of predicting oil and gas potential is increased, the effectiveness of prospecting, detection and technical preparation for further development of the field is increased, and the efficiency of the resource base is increased.

\section{REFERENCES}

[1] K. Otsuka, Y. Kudo, and N. Fuwa, "Introduction to the special issue on revisiting the role of human capital in development", Developing Economies, 2018, vol. 56, № 2, pp. 78-81.

[2] O. Iljashenko, I. Bagaeva, A. Levina. Strategy for establishment of personnel KPI at health care organization digital transformation (2019) IOP Conference Series: Materials Science and Engineering, 497 (1), № 012029.

[1] S.A. Basher, A. A. Haug, P. Sadorsky «The impact of oil-market shocks on stock returns in major oil-exporting countries». Journal of International Money and Finance, vol. 86, September 2018, pp. 264280 https://doi.org/10.1016/j.jimonfin.2018.05.003

[2] Y. Tuzova, F.1 Qayum «Global oil glut and sanctions: The impact on Putin's Russia». Energy Policy, vol. 90, March 2016, pp. 140-151 https://doi.org/10.1016/j.enpol.2015.12.008

[3] A. Vatansever «Is Russia building too many pipelines? Explaining Russia's oil and gas export strategy». Energy Policy, vol. 108, September 2017, pp.. 1-11 https://doi.org/10.1016/j.enpol.2017.05.038

[4] A. Goppert, D. Ola, S. Prakash «Methanol and energy of the future. When will the oil and gas run out?» M .: Publishing house: "BINOM. Laboratory of Knowledge ", 2015. - 173p.

[5] V.V. Stupin «Territorial and structural changes in the oil industry of the world» .Free electronic library. Access mode: http://diss.seluk.ru/av-zemlya/793491-1-territorialno-strukturniesdvigi-neftyanoy-promishlennosti-mira.php (appeal date 21.03.2019).

[6] A. Bondar «Due to US sanctions, Europe began to actively buy expensive Russian oil». European News. Access mode: https://replyua.net/europe/143005-iz-za-sankciy-ssha-evropa-nachalaaktivno-pokupat-doroguyu-rossiyskuyu-neft.html (the date of appeal is $01 / 04 / 2019$ ).

[7] I.V. Filimonova, L.V. Eder, V.Yu. Nemov, I.A. Agile «Production, processing and export of oil and oil products in Russia». Bulletin of the Tyumen State University, 2017, №4, 72p.

[8] R. Ivanov «Three scenarios of the development of the world energy industry until 2050 - experts». 365 Info. Access mode: https://365info.kz/2017/06/tri-stsenariya-razvitiya-mirovoj-energetikido-2050-goda-eksperty (access date 16.04.2019).

[9] Changes in the geographical structure of the world oil market. Center for Macroeconomic Analysis and Short-term Forecasting. Access mode:

http://www.forecast.ru/_ARCHIVE/Analitics/RVolkov/Oil_13.07.25. pdf (appeal date 03/24/2019).

[10] Foreign Economic Strategy of the Russian Federation until 2020. Ministry of Economic Development of Russia. Access mode: https://www.rtedc.org/docs/Vneshneekonomicheskaya\%20strategy\%2 0RF.pdf (appeal date 03/26/2019).

[11] Exports from Russia: oil and oil products . Ru-Stat. Access mode: https://ru-stat.com/date-Y2017-2018/RU/export/RU/0527 (the date of contact is $04 / 01 / 2019)$. 
[12] Oil industry: results of 2017 and short-term prospects. Analytical Center for the Government of the Russian Federation. 2018. 28 p. Access mode: http://ac.gov.ru/files/publication/a/15796.pdf (application date 03/04/2019)

[13] Gazprom Neft 2017 Strategic Report. Gazprom Neft. Access mode: https://ar2017.gazprom-neft.ru/download/full-reports/ar_ru_annualreport_pages.pdf (appeal date 04/04/2019).

[14] Report on activities in the field of sustainable development of the group "LUKOIL" for 2017 . Official site of the oil company "LUKOIL".

Access

mode: http://www.lukoil.ru/PressCenter/Pressreleases/Pressrelease?rid=2075 50 (appeal date 04/05/2019).
[15] A.A. Kobzy, O.V. Titova Digital revolution in the oil and gas industry of the Russian federation. Access mode: https://translate.google.ru/\#view= (application date 03/04/2019).

[16] X. F. Wu, G. Q. Chen «Global overview of crude oil use: From source to sink through inter-regional trade». Energy Policy, vol. 128, May 2019, pp.476-486 https://doi.org/10.1016/j.enpol.2019.01.022

[17] L. Aldieri, M. Kotsemir, C. P. Vinci «Environmental innovations and productivity: Empirical evidence from Russian regions». Resources Policy, In press, corrected proof, Available online 6 July 2019, Article $101444 \quad$ https://doi.org/10.1016/j.resourpol.2019.101444 